\title{
Water Shortages and Drinking Water Quality in Rural Southwest Nige- ria: Issues and Sustainable Solutions
}

\section{Sunday B. Akinde ${ }^{1 *}$, Janet O. Olaitan', Temitope F. Ajani ${ }^{2}$}

\author{
${ }^{1}$ Department of Microbiology, Osun State University, P.M.B. 4494, Osogbo, Osun \\ State, Nigeria \\ ${ }^{2}$ Department of Microbiology, University of Ibadan, Ibadan, Oyo State, Nigeria
}

*Correspondence should be addressed to Sunday B. Akinde: akindesb@uniosun.edu.ng

Received 25 April 2019; Revised o8 May 2019; Accepted 18 May 2019

(C) 2019 Akinde et al. Licensee Pan African Journal of Life Sciences. This is an Open Access article distributed under the terms of the Creative commons Attribution License (https://creativecommons.org/licenses/BY/4.0), which permits unrestricted use, distribution, and reproduction in any medium, provided the original work is properly cited.

Nigeria is a highly populated country in West Africa where less than half of the residents have access to safe potable water. Usually characterised by poor socioeconomic infrastructure, the rural people often carry the brunt of this menace. In this paper, we review existing publications and reports on water scarcity and access to potable water in southwestern Nigeria with the view of keeping the subject matter in perspective for policymakers and relevant government agencies and ministries to take urgent steps in addressing the situation. The reported cases of high pathogenic microbial loads, detection of some heavy metals and physicochemical water parameters exceeding the WHO standard for drinking water quality was discussed. The results have serious public health implications. There is, therefore, a need for a paradigm shift from indiscriminate attitudes of water abuse for sustainable solutions to the water challenges.

Keywords: water security, rural water, drinking water quality, sustainable solutions 


\section{1.o INTRODUCTION}

Water is considered vital to life sustainability and plays a critical role in the socioeconomic development of human being and the existence of ecosystems. The limits imposed by the finite and often vulnerable water resources hampers progress in all dimensions of sustainable development [1]. Nigeria, the most populous country in Africa estimated at 190 million people, is among the four West African countries where less than half of the residents have access to potable water [2]. The country has an estimated 267 billion cubic metres of surface water and 92 billion cubic metres of groundwater per annum with over 200 dams and storage capacity that sum up to 34 billion cubic metres [3]. Unlike the developed countries with an estimated 100 to 250 litres/ day access to consumption of clean and safe water per person, an average Nigerian has access to an average of 80 litres/ day of fresh water which barely sustains a moderate living standard to cater for daily activities including drinking, cooking, bathing, flushing toilets, laundry, cleaning, and watering of gardens [4].

Despite the enormous freshwater resource, about 57 million Nigerians do not have access to basic sanitation and clean water while less than $25 \%$ of the population have access to safely managed drinking water [5]. The impact, however, is usually felt by the vast majority of the poor rural dwellers and the vulnerable individuals, including the internally displaced persons. The importance attached to the use of water in different homes covers a wide range of many domestic activities. The usage ranges from drinking to bathing, cooking, laundry, toiletries, and cleaning of surroundings and drains. Inability to have access to water may probably hinder smooth livelihood in homes. It is too expensive to provide a house-to-house pipe-borne water supply because homes are so widely scattered/ dispersed in rural communities. Majority of the people have low incomes and find it challenging to personally fund and or maintain a safe water supply [6]. They also lack the requisite skills to preserve the pipe-borne water source in the absence of government intervention $[6,7]$. Therefore, lack of pipe-borne water and inadequate potable water interventions in the rural areas of southwest Nigeria are directly responsible for continued dependence of the people on untreated surface waters within their vicinity for drinking and other domestic uses [7]. More often, the rural communities depend mainly on seasonal rainwater, ponds, streams, rivers and shallow wells, most of which may be contaminated and inimical to health. About 361,900 people reportedly die yearly due to poor water and sanitation conditions in Nigeria [8]. The statistics, according to, included approximately 60,000 children under the age of five who die from diarrhoea, a disease caused by poor sanitation and contaminated water [8]. Having access to clean water in sufficient quantity is considered fundamental to promoting health and reducing poverty. This sustainable development goal would be far from being achieved in rural southwest Nigeria without proper appraisal of the challenges and recommendation of sustainable solutions. This paper, therefore, reviews the water shortages and drinking water quality with emphases on rural areas of the southwest, Nigeria.

\section{O WATER SECURITY IN NIGERIA: MATTERS ARISING}

Water is a universal solvent with no alternative. Its importance is innumerable, but specifically, water is said to be living in itself. It is an essential building block of life and more than to quench thirst or protect the health, it is vital for creating jobs and supporting socioeconomic and human development. Worldwide, around 1.2 billion people live in areas of physical water shortages [9].

Nigeria located between latitudes $4^{\circ}$ and $14^{\circ}$ North and longitudes $2^{\circ}$ and $15^{\circ}$ East with a landmass of about 923,770.00 sq. kilometres is sub-divided into six geopolitical zones; one of which is the South West comprising Ekiti, Ondo, Osun, Oyo, Ogun and Lagos States (Figure 1) with human population of about 2.38, $3.44,3.42,5.59,3.73$ and 9.01 million respectively [10].

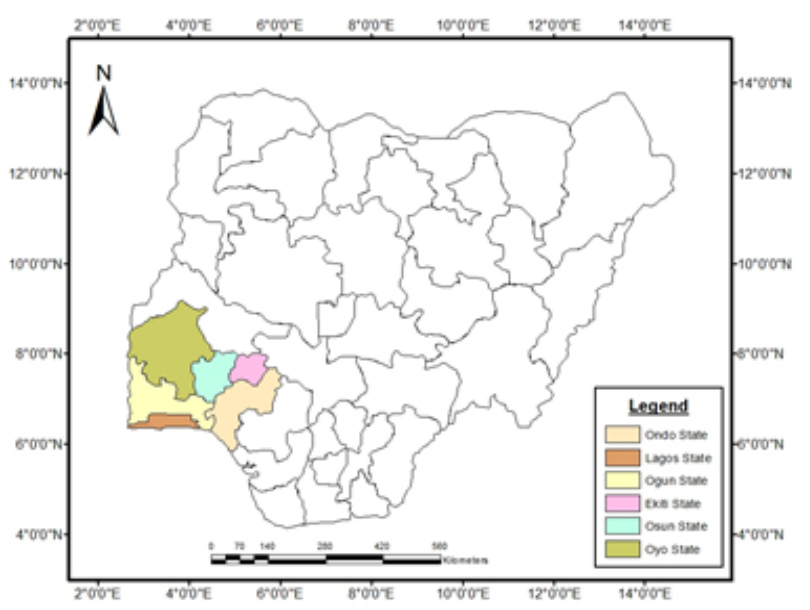

Figure 1. Map of Nigeria Showing the Southwest States

Currently, there are over 66.3 million people in Nigeria living without a safe water supply close to homes, and as such have to spend at least 30 minutes to 2 hours every day queuing and trekking to distant sources to fetch water; not minding its quality [11]. Elderly, women, children, people with disability, refugees, marginalised and impoverished people, especially in rural areas, are more vulnerable and disadvantaged to access and 
manage the safe water they need [11]. This scenario plays out virtually in most southwest states, except in Lagos State, which has one of the highest rates of supply of pipe -borne water. During the colonial administration between 1946 and 1956, provision of water supply system took about $15.1 \%$ of the country's total capital expenditure [12]. Also, since independence, the development of water supply infrastructure has reportedly gulped a lot of money but with little or no water to show for it.

In Nigeria, provision of clean water and sanitation services is the statutory responsibility of the government at federal, state and local levels. However, government commitment to the provision of water supply, in reality, is uncertain due to limited resources and increasing population [13]. It is regrettable that access to safe pipeborne water supply among Nigerians decreased extensively from $14 \%$ in 1990 to $6 \%$ in $2008[14,15]$. The consequence is felt more in rural areas where the people have to depend mainly on unprotected, unsafe and contaminant-prone water sources, including rivers, streams, ponds, and shallow wells for their water needs. According to a World Bank study in 2012, it costs the government one hundred and fifty Naira (N15O) on average, to produce a litre of clean drinking water. The cost is in contrast to private water packaging companies who can sell (with a high-profit margin) a litre of bottled water at less than one hundred Naira (N100) [3]. Successive Governments had always promised an improved and a better standard of living through human development and provision of necessary socio-economic infrastructural facilities among other campaign rhetoric (s); the empirical reality is contrary to the hopes, aspirations and yearning of the populace. In 2018, Nigeria was identified as "The poverty capital of the world" [16] because about 87 million Nigerians (about $45 \%$ of Nigeria's population) are living in poverty. According to the Human Development Index Rating, 91.6 million Nigerians (about $48 \%$ of Nigeria's Population) are in extreme poverty [17].

Among the indices used for this survey are access and affordability to safe water; the purchasing power of at least N693.50 per day; income distribution; production and consumption of basic needs of life amongst others. However, commendable efforts from well-meaning individuals, group(s) of people, religious bodies, corporate organisations, political drives, senatorial constituency projects as well as international organisations/ donors have contributed to favourable access to safe water and sanitation in Nigeria. Notable among the international organisations/donors are UNICEF, Japanese International Cooperation Agency's
(JICA) rural water supply projects, United Nations Development Project (UNDP)-Rural Water supply and European Union (EU) water and sanitation programme. Others include the Department for International Development's (DFID) water and sanitation project, Water Aid's rural water supply and sanitation programme, United State Agency for International Development, World Health Organization and the World Bank.

The geometric increase in population and industrialisation have brought about increase in water needs, especially of higher quality, for a variety of human activities including drinking, personal hygiene, wastes disposal, agriculture (fishing and irrigation), recreation and other domestic as well as industrial demands [18]. The development, also, has led to reduced quality of many lakes, rivers, estuaries and groundwater bodies with devastating consequences on public health, agricultural and industrial production, ecological functions, and biodiversity [19]. In a scientific monitoring investigation of irrigation water and fresh vegetables in southwest Nigeria, Akinde et al. [20] reported the presence of mycotoxin-producing fungal species in irrigation water, cultivation soil, and fresh vegetables. Molecular characterisation revealed that sixteen of the fungal species were aflatoxin B1 producing Aspergillus species in which Aspergillus japonicus (AWF27) isolated from the irrigation water had the highest concentration (106 $\mu \mathrm{g} / \mathrm{kg})$ and Aspergillus fijiensis (ASF6) isolated from the soil had the lowest frequency of $93 \mu \mathrm{g} / \mathrm{kg}$. However, the associated public health risks that may emanate from the presence of pathogenic aflatoxin-producing fungi in irrigation water is not only in the cross-contamination of the soil and or vegetables planted but also in the potential exposure of humans along the food chain [20]. Understanding the seasonal fluctuations of water is fundamental to developing sustainable water resources management and policies. Availability of water during the driest period of the year is crucial to meeting water demand of human activities, and this should be a priority for sustainable management. There is always scarcity of water in the dry season (usually from January to May) annually, but ironically flooding occurs in the rainy season due to inability to manage the naturally abundant water resources.

As society develops, their water usage pattern changes. Global trends in the use of different water sources demonstrate a shift towards piped borne water as a safe water supply. In Nigeria, piped borne water can only be obtained epileptically in old localities as newly developed ones were never integrated into the piped borne water 
supply chain. Poor water quality coupled with unsanitary conditions and practices at the household levels, such as the absence of sanitary latrines, hazardous waste disposal, over-crowding, and unhygienic food preparation creates a dangerous environment with health risks to many rural households [21]. Sanitation fundamentally is any system that encourages healthy living conditions. It also includes methods to manage wastewater, stormwater, solid waste, household refuse as well as ensuring that people have access to safe water in sufficient quantity for drinking and other activities. Globally, $80 \%$ of about 1.8 billion people who use unsafe and unprotected water sources, contaminated with faeces, live in rural areas, putting them at risk of contracting cholera, dysentery, typhoid, diarrhoea and polio among other water-borne diseases [21]. Unsafe water, poor sanitation and hygiene cause around 842,000 deaths each year [22]. The most vulnerable group include the children under five years of age, who die daily from diarrhoea linked to unsafe water and poor sanitation. Women and girls are not left out as they are responsible for water collection in eight out of ten households with water off-premises [8]. In Nigeria, there is an increase in the number of internally displaced persons (IDP) with about 868,000 people identified as at the end of 2014 and close to 1.7 million people by June 2017 [23]. UNDESA [24] posited that almost half the world's population would be living in areas of high water stress by 2030, including between 75 million and 250 million people in Africa.

\subsection{WATER DEMAND AND AVAILABILITY IN RURAL SOUTHWEST NIGERIA: CASE STUDIES}

Availability of fresh water that is sustained by earth's water cycle varies widely with geographical locations. Although southwest Nigeria has ample surface and groundwater sources, clean water supply is still inadequate [25]. The situation becomes worse by the rapid increase in water demand as a direct consequence of population growth and increased human anthropogenic activities in southwest Nigeria. According to findings by Lukman et al [26] on the effect of selected factors on water supply and access to safe water in Nigeria, the average national access to reliable water supply was $45.9 \%$ of which the average widespread access to piped water supply, protected wells, boreholes and water vendors were $17.5,12.8,11.6$ and $4.0 \%$ respectively. With respect to Adejuwon et al [27] on community awareness and evaluation of surface water bodies in Osogbo, the Osun State Capital, the rate of obtaining water varied from regularly $(19.6 \%)$ to rarely (28\%) while the reasons for obtaining the water ranged from its natural state (5.9\%) to lack of potable water source $(27.4 \%)$. They observed that $52.7 \%$ of the residents had contacted one disease or the other including schistosomiasis (6.2\%) and malaria (18.1\%), due to the use of water while scarcity during the dry season has often resulted in frequent clashes among most users. Ojo [28] conducted a study on water supply-demand characteristics and safe water availability and accessibility in eleven selected rural areas in seven Local Governments of Osun State, southwest Nigeria. The work revealed water demand deficits of 20 99\% with associated health consequences/ implications on the inhabitants. With increased population projection of the studied communities, the author predicted a further worsening of the water supply-demand situation unless the water supply systems are improved. In a study conducted by Fadare and Olawuni [21] on domestic water supply and health of households in the three residential densities in Osogbo, Osun State, South West, Nigeria, only about $\mathbf{2 3 . 8 \%}$ of respondents in the high residential density had access to a public tap and private well in their houses. Also, the incidence of diarrhoea (23.3\%), stomach ache (20.2\%) and typhoid (14.8\%) were higher than the other two residential densities. The study revealed that there was a significant relationship between water sources and ill health in the three residential densities in Osogbo, the Osun State capital, despite the supply of water from three primary sources: pipe borne water, boreholes and wells.

\section{O WATER QUALITY IN RURAL COMMUNITIES OF SOUTHWEST NIGERIA}

Water quality monitoring conducted on six selected surface water catchments in Obokun rural communities of Osun State reported the presence of nitrate $\left(\mathrm{NO}_{3}\right)$ and magnesium $(\mathrm{Mg})$ in the values ranging from $50.0-154.0$ $\mathrm{mg} / \mathrm{L}$ and $20.0-110.0 \mathrm{mg} / \mathrm{L}$ respectively exceeding the WHO Standard for Drinking Water Quality recommendation for potable water [7]. All the surface water sampled in the studied area contained total heterotrophic bacteria (THB) $(1100-5900 \mathrm{cfu} / \mathrm{mL})$; total coliforms (9.00 - 78.00 cfu/10oml); total heterotrophic fungi (THF) $(1.00-7.00 \mathrm{cfu} / \mathrm{ml}$ density range); thermotolerant coliform (4.0 - 11.0 cfu/10oml); Escherichia coli $(4.00-7.00 \mathrm{cfu} / 100 \mathrm{ml}) ;$ faecal Streptococci $(1.00-5.00$ $\mathrm{cfu} / \mathrm{ml})$ and Salmonella $(1.00-8.00 \mathrm{cfu} / 100 \mathrm{ml})$. Shigella $(1.00-6.00 \mathrm{cfu} / 100 \mathrm{ml})$ were also detected in some of the samples. The presence of such pathogenic microorganisms in water samples is indicative of faecal contamination. The qualities of surface water samples used for this study were, therefore, not suitable for human consumption without adequate treatment. However, most rural community people still rely on surface water for drinking and other domestic use. Identification of costeffective local water treatment techniques and implementation of WHO Water Safety Plan (WSP) will 
Akinde et al. Pan African Journal of Life Sciences (2019): 2: 85-93

improve water quality and minimise risks to human health [7].

The findings on the prevalence of waterborne diseases and microbial assessment of drinking water quality in Ado - Ekiti and its environs, revealed that $27.7 \%$ of waterborne diseases are associated with poor microbiological quality of the water samples [29]. The Microbiological assessment of the water samples showed that 21\%; $73.6 \%$; and $47.2 \%$ did not meet the WHO standard for the total viable bacterial count (TVBC); total coliform count (TCC) and E. coli count respectively. The detection of total coliforms and E. coli in some of the water samples from the different water sources in AdoEkiti and its environs in large colony forming unit implies that the contaminated drinking water may be responsible for the prevalence of waterborne diseases in the studied areas. The authors opined that effort should be made by appropriate authorities to conduct a quality assessment of water sources from time to time to ensure that safe drinking water of good quality is available to everyone.

The quality of groundwater randomly collected from twelve hand-dug wells in Orereowu, Ajilosun and Olorunda areas in Ado-Ekiti, Nigeria, revealed that the water samples collected from Orereowu area had the highest Most Probable Number (MPN) values for bacterial counts, highest lead and cadmium compared to other localities [30]. Also, the MPN from Olorunda area exceeded the limits prescribed by the WHO Standard for Drinking Water Quality, thus rendering them unfit for drinking purposes without pretreatment. In a study conducted among residents in a slum area, in Ibadan, it was reported that shortage of water was a factor responsible for common illnesses in children, ranging from $0-5$ years of age [31]. Consequent upon the general lack of access to pipe-borne water, the bulk of the respondents (83.5\%) depended on well water for domestic and other purposes. Other sources of water supply to households were borehole (10.5\%) and nearby stream (1.0\%). Some respondents, however, relied on water vendors (3.5\%) [31]. In the same vein, communities in Ogbomoso South, Ogbomoso North, Orire and Surulere local governments respectively had $87.3 \%$, $83.3 \%, 84.6 \%$ and $76.5 \%$ of their respondents using hand -dug wells as the primary sources of water [32]. However, water in the hand-dug wells is usually low during the dry seasons. Assessment of well water pollution by sewage contaminants in Akure South, Ondo State [33], revealed the extent of well water contamination in dry and rainy seasons through the infiltration of coliform bacteria from sewage pits in their proximity to the hand-dug wells. Total and faecal coliform counts of twenty household wells were investigated between March and July concerning the proximity of wells to sewage pits, the orientation of wells to sewage pits, and other well's characteristics. All the wells investigated were vulnerable to contamination with observable differences in features, physicochemical parameters, total coliform counts and faecal coliform counts. The $\mathrm{pH}$ of the water samples had higher values in the dry season than all other parameters with lower concentrations. At an average distance of 17.6 $\mathrm{m}$ from the sewage pits, all the well water sampled had greater coliform counts than the WHO threshold recommendation for drinking water. There was a positive but non-significant correlation between coliform counts of the water samples and the distances of the well to the sewage pits for both total and faecal coliform in the dry season but negative and significant in the rainy season. It means that coliforms found in the wells were significantly affected by seasonal variations. Therefore, siting of handdug wells upgradient and away from the sanitary systems has the potential to reduce ground/ surface water pollution and prevent the occurrence of waterborne diseases.

In the findings of Olugbamila and Ogunyemi [34] on assessment of water supply situation in Owo, Ondo State and implication for the attainment of the Millennium Development Goals (MDGs); there was a shortage of potable water as well as lack of attention to maintenance and sustainability. Majority of the respondents got their water supplies from unprotected sources, thereby making them vulnerable to water-borne diseases.

In Ogun State, the water supply varied dramatically from one area to another, and so did the cost. In Abeokuta, the state capital, most people have access to public taps while in some localities, the consumer pays exorbitantly for water from private vendors [35]. Households' water-use demand and willingness to pay for improved water services was studied in ten sub-zones of Ijebu Ode local government area of Ogun State. The study identified private piped/ boreholes (64.8\%), public piped (18.5\%) and wells (16.7\%) as the majority of households' water supply. The public piped (64.4\%) was the most preferred water choice followed by a private piped/ boreholes (30.1\%) and hand-dug wells (5.6\%) as determined by quality, convenience, availability and cost. The authors recommended the facilitation of improved public water utilities by the government and donor agencies to cover all the sub-zones of Ijebu Ode and its environs [15] Chinedu et al [36] analysed water samples from Iju river, precipitation rain, borehole, tap, unchlorinated swimming pool from Covenant University, bottled and sachet with branded labels, production line and effluent of Intercontinental Distillers Limited as well as receiving 
rivers from effluents of Canaan land for their biological and physicochemical properties. They found out that the potable water samples from tap, borehole, and bottled/ sachet labels were within the standards for consumable water and so are considered safe for human consumption. The surface waters, on the other hand, had high levels of total dissolved solids, conductivity and salinity. The BOD of the effluent water showed that the water was contaminated and the use of the water for domestic purposes by the inhabitants could lead to dangerous side effects.

In Lagos State, about $80 \%$ of the people reside in the metropolitan area, while the remaining $20 \%$ live in the riverine areas [37]. Accessibility to potable water in sufficient quantity depends mostly on the affordability of the available options. Assessment of the status of water supply and sanitation service levels in 20 rural communities of Amuwo Odofin and Ojo local government area of Lagos State identified hand-dug wells and boreholes fitted with either electric or hand pumps as the primary water supply facilities used by the communities [38]. These findings showed that the water supply service level is generally low across the study areas a situation not unconnected with borehole failure and abandonment of hand dug wells due to saltwater intrusion. High coliform bacterial counts in the range of $1.10 \times 10^{2}$ and $1.80 \times 10^{2}$ $\mathrm{CFU} / \mathrm{ml}$ observed in water samples from 16 out of the 20 rural communities was an indication of possible faecal contamination. The contamination of available water sources observed in all the communities was attributed to the poor sanitation practices. Active community participation in the provision and management of improved sanitation facilities to ensure improved water quality was recommended [38].

\section{O FACTORS RESPONSIBLE FOR SHORTAGES AND DECLINE IN DRINKING WATER QUALITY}

Factors responsible for water shortages and a decline in water quality in rural communities are enormous. These factors include limited and highly polluted watercourses, fast-growing population and predominant communal behaviours of urination and dumping of refuse and sewage into water bodies, industrialisation on a small- to mediumscale leading to the discharge of wastewater into the environments (water bodies) without pretreatment. Also implicated is environmental damage worsened by floods, drought/ degraded vegetation, soil, rivers and lakes, contamination with chemical runoff and microbial pathogens. Low and seasonal fluctuation of rainfall, high evaporation rates, mining activities leading to acidification of water bodies, power generation, climate change, deforestations, haphazard land use patterns, lack of government policies implementation, and poor community mobilisation are among the factors responsible for water shortage [39]. There were sponsored boreholes and motorised hand-dug wells in some communities in Nigeria. Most of these are not functioning due to improper selection of contractors and poor job delivery [40]

\subsection{CONSEQUENCES OF WATER SHORTAGES AND CONTAMINATION}

Water availability in sufficient quantity and quality, as well as the ease to access, is a significant factor in raising the socio-economic and health standards of any society. It is a critical component in poverty alleviation efforts and reflects the hygiene and sanitation of people in the country. Enhancing water resources to adequate quantity and quality for domestic and even industrial uses are, therefore, essential for sustainable socio-economic development. Within the context of existing socio-physical and housing environmental conditions, the prevalence of environment-related communicable diseases in eighteen communities in Ogbomoso, Oyo State was examined [32]. The authors used a combined social survey of residents perception and six months hospital records of clinically diagnosed infections to study the incidence, prevalence, gender and spatial dimensions of four major waterborne communicable diseases namely: malaria, typhoid, cholera and diarrhoea. They observed a general lack of infrastructural facilities with poor accessibility to houses as the direct consequence of the communities' prevalence to the studied diseases. Populations with malaria are on the increase in tropical sub-Saharan Africa, especially in unsanitary rural areas, where community waste disposal facilities are lacking, and water containing wastes makes excellent anopheles mosquitoes breeding sites [32]. The delayed development and human challenge posed by malaria in Africa are unprecedented. The adverse effects of insufficient water supply as it affects the health of the people of Kajola local government area in Oyo State, Nigeria was studied [41]. During the three weeks of study in the community, the authors recorded various forms of water-borne diseases including typhoid fever, diarrhoea, paratyphoid fever and bacillary dysentery. Health-related problems were further aggravated by population growth without a significant improvement in infrastructure. Other water-borne diseases transmissible within southwest Nigeria include cholera, schistosomiasis, and hepatitis. A sufficient supply system represents a worthwhile and lasting investment which would benefit all by improving hygiene and reducing waterborne diseases.

\subsection{SUSTAINABLE SOLUTIONS OF WATER SHORTAGES AND CONTAMINATION IN NIGERIA}

Faced with the reality of water shortages and poor drinking water quality in rural southwest Nigeria, the sustainable solution requires holistic cooperation among 
all the stakeholders. In addition to the various global, regional and national commitments to achieve universal access to water and sanitation in a range of agreements, the local water authorities as well as the affected communities must be honest and ready to face the challenges head-on. Water for all by 2030 is one of the sustainable development goals (SDG) with the overall aim of achieving access to quality water in adequate supply [42]. Therefore, to meet the SDG 6 in Nigeria, all hands must be on deck for action plans committed to understanding the associated water risks with holistic reasoning as to why this naturally abundant resource is far from being usefully available. The possible solutions to minimising these risks, as well as adequate measures to boosting water development in the state, are presented hereunder.

Water supply systems with modern infrastructure are expensive to construct and maintain, especially in rural communities. There is need to facilitate the development of relevant policies and crosscutting frameworks to promote a wide range of water management practices that protects, restores, or mimics the natural water cycle in the area $[43,44,45]$. Provision of green infrastructure, a costeffective and resilient approach, is the prime step towards a sustainable water use in a green economy like rural southwest Nigeria. Suggested practices include but not limited to wetland/ stream buffers [46], forest/ landscape restoration [47], rain gardens [48] and porous pavements $[49,50]$. Green infrastructure plays a crucial role in increasing water quality in associated streams, rivers, and lakes, thus providing environmental benefits. In addition to managing stormwater, green infrastructure can recharge groundwater, provide wildlife habitat, beautify neighbourhoods, remove contaminants such as heavy metals, microorganisms, turbidity, etc. and improve air quality. Establishment of an integrated waste management system could be used to address the contamination of the water resources due to deliberate waste discharge or increased forestry activities. More importantly is the collection, storage, and disposal of domestic wastes [51, 52]. Wastewater from small and medium-scale industries springing up in the rural communities would be a valuable resource if reduced, treated, recycled and reused [53, 54]. Especially the reuse of treated wastewater for irrigation purpose [54].

Other authors proposed the use of bioflocculant from microorganisms for wastewater treatment, thereby exploiting nature-based solutions to solving water and other environmental challenges [55]. Adoption of a Water Safety Plan (WSP) as a practical risk assessment framework could elaborate in real-time the possible physical, chemical and biological hazards associated with water resources and the supply systems [56]. If properly designed, the WSP will augment the traditional monitoring and resolution practices to ensure the promise of quality water for all in the study communities. People with safe water and adequate sanitation are reported to have significantly lower odds of a Schistosoma infection [57]. This observation could produce similar results for several water-borne diseases [58]. Therefore, there is a need for improved water sanitation and hygiene (WASH) as a deliberate individual and communal practice. A package of WASH interventions and sensitizations comprising general sanitation, water improvement, handwashing with soap, ending open defecation and food hygiene should be part of the strategic government policies for implementation in the rural areas [42].

Sustainable reduction in water shortages and improved drinking water quality requires adequate hygiene and sanitary education. Such training would sensitise the rural dwellers as to how to handle their wastes and take care of their environments to prevent waterborne diseases which stem from poor hygiene. Khan [59] reported that in Karachi, Pakistan for example, a study found that poor people living in an area without any sanitation or hygiene education spent six times more on medical care than people who lived in areas with access to sanitation and who had basic knowledge of household hygiene.

\subsection{CONCLUSIONS AND RECOMMENDATIONS}

There is inadequate water supply systems and impaired drinking water quality in rural southwest Nigeria. Although the area, blessed with surface water and groundwater resources, its potential for ensuring adequate water in required quality is far from reality. The challenges are mainly associated with human activities, lack of infrastructure and improper implementation of both local and international policies and regulations on water management. A holistic action plan which requires a participatory approach by all the stakeholders is the only sustainable strategy towards the achievement of adequate quality water for all by 2030 in rural southwest Nigeria. The proposed options included the provision of green infrastructure, implementation of integrated waste management practices, water, sanitation and hygiene interventions, the introduction of WSP, community awareness and education, and provision of renewable energy. Each of the proposed sustainable solutions, when rightly utilised, will not only rebalance the water cycle but will improve human health and livelihoods in the rural communities.

\section{Conflict of interest}

The authors declare that there is no conflict of interest. 


\section{Authors' Contributions}

SBA conceived and designed the study, contributed to the writting of the manuscript, map design and revised the manuscript ; JOO and TFN Contributed to the writing and revised the manuscript.

\section{Acknowledgement}

The authors appreciate the intellectual prowess of all the cited scholars for making the information available and accessible in the public domain. The extensive review by M.A. Adeleke is highly acknowledged. We thank M.A. Ebire for producing the map of southwest Nigeria.

\section{References}

1. Brack W, Altenburger R, Schüürmann G, Krauss M, Herráez DL, Van Gils J, Slobodnik J, Munthe J, Gawlik BM, Van Wezel A, Schriks M. The SOLUTIONS project: challenges and responses for present and future emerging pollutants in land and water resources management. Science of the Total Environment. 2015; 503: 22-31.

2. UN-Water. "Event to mark World Water Day 2016 and launch the World Water Development Report". International Labour Organisation. 2018; Retrieved 20 March 2018.

3. Egbinola $\mathrm{CN}$. The trend in access to safe water supply in Nigeria. Journal of Environment and Earth Science. 2017; 7(8): 89-96.

4. Idowu OA, Martins O, Ajayi O. Groundwater Occurrence in Southwestern Nigeria: A Comparison of Two Geological Environments. Water Res. 1998; 9: 33-40.

5. WHO/UNICEF. Progress on Drinking Water, Sanitation and Hygiene: 2017 Update and SDG Baselines. Geneva: World Health Organization (WHO) and the United Nations Children's Emergency Fund (UNICEF), 2017. 2017.

6. Muta'aHellandendu J. Health implications of water scarcity in Nigeria. European Scientific Journal. 2012; 8(18): 111-117.

7. Olaitan JO, Akinde SB, Salami AO, Akinyode OA. Quality surveillance of surface water catchments in selected Obokun rural communities, in South-Western Nigeria. African Journal of Microbiology Research. 2013; 7(36): 4491-4500.

8. WHO. Safely Managed Drinking Water - Thematic Report on Drinking Water 2017. World Health Organization: Geneva, Switzerland. 2017

9. Ibe-Lamberts K. The relationship between water scarcity awareness by transnational Nigerians and its effect on the willingness to contribute to water scarcity relief efforts in Nigeria. Doctoral dissertation, the University of Illinois at Urbana-Champaign. 2012; 40pp.

10. National Population Commission. Population and housing census of the Federal Republic of Nigeria. Priority Tables. $2006 ; 1$.

11. UN-Water. "World Water Day Theme 2019 Factsheet ". 2019; Retrieved 7 February 2019.

12. Aminu FT. Natural resources and land use. Workshop on Environment and Sustainable Development, NCEMA, Ibadan August 2000. 2000.

13. Ndaw MF. Private Sector Provision of Water Supply and Sanitation in Rural Areas and Small Towns: The Role of the Public Sector-Guidance Note. The World Bank. 2016.

14. WHO/UNICEF JMP. Progress on Sanitation and Drinking Water; 2010 Update, WHO, Geneva. 2010; ISBN 97892
41563956.

15. Coster AS, Otufale GA. Household's water-use demand and willingness to pay for improved water services in Ijebu-Ode Local Government Area, Ogun State, Nigeria. Journal of Environment and Earth Science. 2014; 4: 166-174.

16. World Poverty Clock. Human Development Index 2018. Vienna-based World Data Lab; June 2018. 2018.

17. World Poverty Clock. Human Development Index 2019. Vienna-based World Data Lab; February 13, 2019. 2019.

18. Turdukulov UD. Determination of water quality parameters using imaging spectrometry (Case study of Sajo floodplain, Hungary). The International Research Institute for Geoinformation. 2003

19. Davis R, Hirji R. Water quality: assessment and protection. Water Resources and Environment - Technical Note D.1. The World Bank. Washington, D.C. 2003.

20. Akinde SB, Olaitan JO, Ajayi EI, Adeniyi MA, Ige OO, Adebooye OC. Fungal quality and molecular characterisation of aflatoxin-producing Aspergillus species in irrigation water and fresh vegetables in southwest Nigeria. Jordan Journal of Agricultural Sciences. 2018; 14(1): 51-70.

21. Fadare SO, Olawuni PO. Domestic water supply and health of households in the three residential densities in Osogbo, Osun State, Nigeria. Ethiopian Journal of Environmental Studies and Management. 2008; 1(2): 35-43.

22. WHO/UNICEF. Meeting the MDG Drinking Water and Sanitation Target; Mid-Term Assessment of Progress; WHO: Geneva. 2014.

23. UNHCR. Nigeria situation - supplementary appeal: January - December 2017 (Revised July 2017), https://reliefweb.int/ report/nigeria/nigeria-situation-2017-supplementary-appeal -january-december-2017-revisedjuly-2017. 2017.

24. UNDESA. 'Water for Life' 2005 - 2015. International Decade for Action. United Nations Department of Economics and Social Affairs. https://www.un.org/waterforlifedecade / scarcity.shtml. Retrieved: April 2019. 2019.

25. Adekalu KO, Osunbitan JA, Ojo OE. Water sources and demand in South Western Nigeria: implications for water development planners and scientists. Technovation. 2002; 22 (12): 799-805.

26. Lukman S, Ismail A, Asani MA, Bolorunduro KA, Foghi PU, Oke IA. Effect of selected factors on water supply and access to safe water in Nigeria. Ife Journal of Science. 2016; 18(3): 623-639.

27. Adejuwon JO, Adekitan AA, Oladunmoye Sl. Community awareness and evaluation of surface water bodies in Osogbo, Osun State, Nigeria. J. Appl. Sci. Environ. Manage. 2018; 22 (10): 1567-1571.

28. Ojo O. A study of the rural water supply-demand situation in South West Nigeria. WIT Transactions on Ecology and the Environment. 2011; 145: 51-61.

29. Olowe BM, Oluyege JO, Famurewa O. Prevalence of waterborne diseases and microbial assessment of drinking water quality in Ado-Ekiti and its environs, Southwestern, Nigeria. Prevalence. 2016; 10: 15 .

30. Dada TE, Awokunmi EE, Falegan CR, Olanipekun EO. Status of groundwater quality in selected areas of Ado-Ekiti, Nigeria WIT Transactions on Ecology and the Environment, Water Resources Management. 2011; 145: 339-348.

31. Osinusi K, Oyejide C. "Morbidity pattern among Nigerian children from a poor urban community". African Journal of Medicine and Medical Sciences. 1989; 18:43-47.

32. Adeboyejo AT, Abolade O, Oshinowo T. The prevalence of 
environment-related diseases in peri-urban areas of Ogbomoso, southwest, Nigeria. Ethiopian Journal of Environmental Studies and Management. 2009; 2(2): 73-83.

33. Owoeye JA, Akinneye JO. Assessment of well water pollution by sewage contaminants: A case study of Akure South, Ondo State, Nigeria. Brazilian Journal of Biological Sciences. 2018; 5(10): 549-575.

34. Olugbamila OB, Ogunyemi OF. Assessment of water supply situation in Owo, Ondo State, Nigeria: Implications for the Attainment of the Millennium Development Goals. Int $\mathrm{J}$ Scientific Res Publications. 2015; 5(9): 180-185.

35. OGS.W.C. Ogun State Water Corporation Investment Plan OGS.W.C. Presidential Boulevard, Oke-Imosan, Abeokuta, Nigeria. 2010; pp1-74

36. Chinedu SN, Nwinyi OC, Oluwadamisi AY, Eze VN. Assessment of water quality in Canaanland, Ota, Southwest Nigeria. Agriculture and Biology Journal of North America. 2011; 2(4): 577-583.

37. Longe EO, Williams A. A preliminary study of medical waste management in Lagos metropolis, Nigeria. Iran Journal of Environmental Health Science and Engineering. 2006; 3(2): $133-139$.

38. Longe EO, Yaya FM. Assessment of Water and Sanitation Service Levels in 20 Rural Communities of Amuwo Odofin and Ojo Local Government Areas of Lagos State, Nigeria. American Journal of Environmental Engineering and Science. 2015; 2(6): 53-61.

39. Yaya OO, Dossah B, Chukwurah MA. An appraisal of handpump boreholes in Zamfara State; Nigeria. 29th WEDC International Conference, Towards the Millennium Development Goals, Abuja, Nigeria. 2003.

40. Akpabio EM. Water Supply and Sanitation Services Sector in Nigeria: The Policy Trend and Practice Constraints. ZEF Working Paper Series, ISSN 1864-6638 Department of Political and Cultural Change Centre for Development Research, University of Bonn Editors: Joachim von Braun, Manfred Denich, Solvay Gerke, Anna-Katharina Hornidge and Conrad Schetter. 2012.

41. John-Dewole OO. Adverse effects of inadequate water supply on human health: a case study of Kajola Local Government in Oyo State, Nigeria. Greener Journal of Medical Sciences. 2012; 2(5): 115-119.

42. Hutton G, Varughese M. The costs of meeting the 2030 sustainable development goal targets on drinking water, sanitation, and hygiene. The World Bank. 2016.

43. Mell IC. Green infrastructure: concepts and planning. In FORUM E-journal. 2008; 8(1): 69-80.

44. Maes J, Barbosa A, Baranzelli C, Zulian G, e Silva FB, Vandecasteele I, Hiederer R, Liquete C, Paracchini ML, Mubareka S, Jacobs-Crisioni C. More green infrastructure is required to maintain ecosystem services under current trends in land-use change in Europe. Landscape Ecology. 2015; 30(3): 517-534.

45. Shackleton CM, Blair A, De Lacy P, Kaoma H, Mugwagwa N, Dalu MT, Walton W. How important is green infrastructure in small and medium-sized towns? Lessons from South Africa. Landscape and Urban Planning. 2018; 180: 273-281.

46. Castelle AJ, Johnson AW, Conolly C. Wetland and stream buffer size requirements - a review. Journal of Environmental Quality. 1994; 23(5): 878-882.

47. Chazdon RL. Landscape restoration, natural regeneration, and the forests of the future 1. Annals of the Missouri Botanical Garden. 2017; 102(2): 251-258.

48. Vineyard D, Ingwersen WW, Hawkins TR, Xue X, Demeke B, Shuster W. Comparing green and grey infrastructure using life-cycle cost and environmental impact: a rain garden case study in Cincinnati, OH. JAWRA Journal of the American Water Resources Association. 2015; 51(5): 1342-1360.

49. Antunes L, Thives L, Ghisi E. Potential for potable water savings in buildings by using stormwater harvested from porous pavements. Water. 2016; 8(4): 110 .

50. Zhang K, Yong F, McCarthy DT, Deletic A. Predicting long term removal of heavy metals from porous pavements for stormwater treatment. Water Research. 2018; 142: 236-245.

51. Imam A, Mohammed B, Wilson DC, Cheeseman CR. Solid waste management in Abuja, Nigeria. Waste Management. 2008; 28(2): 468-472.

52. Ravindra K, Kaur K, Mor S. System analysis of municipal solid waste management in Chandigarh and minimisation practices for cleaner emissions. Journal of Cleaner Production. 2015; 89: 251-256.

53. Caselles-Osorio A, Mendoza G, Simanca M, Romero-Borja I, Mosquera JE, Eslava P. Tomato (Lycopersicum esculentum) production in sub-surface flow constructed wetlands for domestic wastewater treatment in rural a Colombian community. Ingeniería. Investigación y Tecnología. 2018; 19(4): 110.

54. Cui B, Luo J, Jin D, Jin B, Zhuang X, Bai Z. Investigating the bacterial community and amoebae population in rural domestic wastewater reclamation for irrigation. Journal of Environmental Sciences. 2018; 70: 97-105.

55. Ajani TF, Adebayo-Tayo BC, Alao SO. Screening and effects of production conditions on bioflocculants' production by microorganisms isolated from wastewater. Journal of Science Research. 2016; 15: 70-79.

56. Shamsuzzoha M, Kormoker T, Ghosh RC. Implementation of water safety plan considering climatic disaster risk reduction in Bangladesh: A study on Patuakhali Pourashava water supply system. Procedia Engineering. 2018; 212: 583-590.

57. Grimes JE, Croll D, Harrison WE, Utzinger J, Freeman MC, Templeton MR. The roles of water, sanitation and hygiene in reducing schistosomiasis: a review. Parasites and Vectors. 2015; 8(1): 156 .

58. Taylor DL, Kahawita TM, Cairncross S, Ensink JH. The impact of water, sanitation and hygiene interventions to control cholera: A systematic review. PloS One. 2015; 10(8): 1-19.

59. Khan AH. The sanitation gap: Development's deadly menace. The Progress of Nations. 1997; 1997: 5-13. 